\title{
Gambaran kualitas hidup pasien lansia pengguna gigi tiruan lepasan di RSGM Unpad
}

\author{
Cindy Annisa Melati*, Sri Susilawati*, Rasmi Rikmasari** \\ *Departemen IImu Kesehatan Masyarakat, Fakultas Kedokteran Gigi, Universitas Padjadjaran, Bandung, Jawa Barat, Indonesia \\ **Departemen Prostodonsia Fakultas Kedokteran Gigi, Universitas Padjadjaran, Bandung, Jawa Barat, Indonesia \\ *JI Sekeloa Selatan No 1 Bandung, Jawa Barat, Indonesia; e-mail: cindyannisamelati@gmail.com
}

Submisi: 10 Januari 2017; Penerimaan: 20 April 2017; Publikasi online: 29 Desember 2017

\begin{abstract}
ABSTRAK
Pada lansia terjadi suatu proses menghilangnya secara perlahan kemampuan jaringan untuk memperbaiki diri yang disebut proses menua. Proses tersebut berpengaruh terhadap gigi dan jaringan periodontal sehingga mengakibatkan kehilangan gigi. Jika kehilangan gigi tidak diberi perawatan dapat mengganggu fungsi dan aktivitas rongga mulut sehingga akan mempunyai dampak pada kualitas hidupnya. Penelitian ini bertujuan untuk mengetahui gambaran kualitas hidup pasien lansia pengguna gigi tiruan lepasan di Instalasi Prostodonsia RSGM Unpad. Jenis penelitian adalah deksriptif dengan teknik pengambilan sampel menggunakan teknik populasi terjangkau dengan minimal sampling. Data dikumpulkan dari 31 pasien lansia pengguna gigi tiruan lepasan di Instalasi Prostodonsia RSGM Unpad. Kualitas hidup diukur dengan menggunakan kuesioner GOHAl. Hasil penelitian menunjukkan bahwa dimensi fungsi fisik berada pada kriteria cukup, dimensi nyeri dan ketidaknyamanan berada pada kriteria baik dan dimensi aspek psikososial berada pada kriteria baik. Kesimpulan penelitian menunjukkan kualitas hidup pasien lansia pengguna gigi tiruan lepasan di Instalasi Prostodonsia RSGM Unpad dikategorikan baik.
\end{abstract}

Kata kunci: gigi tiruan lepasan; kualitas hidup; lansia

\begin{abstract}
Description of quality of life on elderly patients with removable denture at RSGM Unpad. The elderlies are prone to the process of the gradual decreasing ability of the tissue for self-healing. This process greatly affects the dental structure and periodontal tissue leading to tooth decay. When it is not properly treated, it may disturb oral functions and activities influencing their life quality. This research, therefore, aims to obtain the description of quality of life on elderly patients with removable denture at the Prosthodontic Clinic RSGM Unpad. Research was conducted with a descriptive method using the consecutive technique sampling method. Data were collected from 31 elderly patients with removable denture at the Prosthodontic Clinic RSGM Unpad and quality of life was measured by GOHAI questionnaire. The results showed that the dimensions of physical function fell into the adequate criteria, while the dimensions of pain and inconvenience and psychosocial aspects were considered good. It can be concluded that the general quality of life on elderly patients with removable denture at the Prosthodontic Clinic RSGM Unpad were good.
\end{abstract}

Keywords: removable prosthodontics; quality of life; elderly

\section{PENDAHULUAN}

Semua individu akan mengalami fase usia lanjut dan pada fase tersebut mereka mengharapkan memiliki kondisi yang sehat, sejahtera, berguna, produktif, berkualitas, dan bermartabat. Menurut Undang-Undang Republik Indonesia No. 13 Tahun 1998 pasal 1 ayat 2 tentang kesejahteraan lanjut usia, lanjut usia adalah seseorang yang telah mencapai usia enam puluh tahun ke atas. ${ }^{1}$

Proporsi jumlah lansia terus berkembang di seluruh dunia, terutama di negara berkembang. Pertumbuhan jumlah lansia cenderung lebih cepat dibandingkan dengan kelompok usia lainnya. Secara global, jumlah penduduk berusia 60 tahun ke atas mencapai 600 juta dan angka ini diperkirakan akan menjadi 2 kali lipat pada tahun 2025. Pada tahun 2050 akan menjadi 2 milyar dan $80 \%$ diantaranya bermukim di negara berkembang. ${ }^{2}$

Populasi lansia di Indonesia menurut Badan Pusat Statistik tahun 2010 mencapai 52.094 .585 jiwa dari 237.641 .326 jiwa total populasi (22\%), sedangkan di Jawa Barat menurut sumber yang sama diperkirakan sebanyak 3.032.937 jiwa. ${ }^{3}$ Diperkirakan jumlah penduduk lanjut usia di Indonesia pada tahun 2025 dapat mencapai 85.321.800 jiwa, jumlah tersebut termasuk jumlah yang cukup besar untuk negara berkembang seperti Indonesia., ${ }^{4,5}$ Meningkatnya usia harapan hidup dapat dipengaruhi oleh majunya pelayanan kesehatan, menurunnya angka kematian bayi dan anak, adanya perbaikan gizi dan sanitasi, serta 
peningkatan pengawasan terhadap penyakit menular. ${ }^{6}$ Peningkatan usia harapan hidup dan bertambah jumlah lanjut usia di satu sisi merupakan salah satu keberhasilan dalam pembangunan sosial dan ekonomi, namun keberhasilan tersebut mempunyai konsekuensi dan tanggung jawab, baik pemerintah maupun masyarakat, untuk memberikan perhatian lebih serius. Hal ini disebabkan bertambahnya usia, kondisi dan kemampuan lanjut usia untuk beraktivitas semakin menurun. ${ }^{7}$

Pada lansia, terjadi penurunan kemampuan akal dan fisik yang salah satunya karena proses menua. Proses menua adalah suatu proses menghilangnya secara perlahan kemampuan jaringan untuk memperbaiki diri atau mengganti dan mempertahankan fungsi normalnya. ${ }^{8}$

Kerusakan gigi, kegoyangan gigi, karies, halitosis, gingivitis, resesi gingiva, hilangnya perlekatan periodontal, dan tulang alveolar merupakan perubahan jaringan periodontal yang umum ditemukan pada lansia. Hal tersebut jika tidak dirawat dapat mengakibatkan kegoyangan dan lepasnya gigi-gigi yang nantinya akan mengganggu fungsi dan aktivitas rongga mulut sehingga akan mempunyai dampak pada kualitas hidupnya. Orang yang kehilangan gigi tersebut membutuhkan gigi tiruan untuk mengembalikan beberapa fungsi gigi.., 9 Hilangnya satu gigi atau lebih dapat digantikan oleh gigi tiruan cekat maupun gigi tiruan lepasan. Perbedaan antara kedua jenis gigi tiruan tersebut adalah dapat atau tidaknya gigi tiruan dilepas oleh pasien sendiri tanpa bantuan dokter. ${ }^{10}$

Kesehatan gigi dan mulut (oral health) menurut World Health Organization (2012) memiliki arti, "Bebas dari nyeri kronik pada rongga mulut dan wajah, kanker rongga mulut dan tenggorokan, luka pada rongga mulut, kelainan konginental seperti bibir atau palatum sumbing, penyakit periodontal, kerusakan dan kehilangan gigi, dan penyakit atau gangguan lainnya yang mempengaruhi rongga mulut". Kualitas hidup (quality of life) menurut World Health Organization (1997) adalah "Persepsi seseorang dalam konteks budaya dan norma yang sesuai dengan tempat hidup orang tersebut serta berkaitan dengan tujuan, harapan, standar, dan kepedulian selama hidupnya. ${ }^{11}$

Gangguan kesehatan gigi dan mulut menjadi salah satu masalah yang berimplikasi negatif terhadap kesehatan secara keseluruhan sehingga pada akhirnya mempengaruhi kualitas hidup pada lansia. ${ }^{12}$ Kesehatan gigi dan mulut pada lansia dinilai dengan menggunakan Geriatric Oral Health Assesment Index (GOHAI), terdiri atas dua belas pertanyaan terbagi dalam tiga dimensi, yaitu fungsi fisik, nyeri dan ketidaknyamanan, dan aspek psikososial. ${ }^{13}$

Berdasarkan latar belakang di atas, penulis tertarik untuk melakukan penelitian mengenai besar tingkat kualitas hidup pada lansia pemakai gigi tiruan lepasan di Instalasi Prostodonsia Rumah Sakit Gigi dan Mulut Gigi Universitas Padjadjaran (RSGM Unpad). Tujuan dari penelitian ini adalah untuk menggambarkan kualitas hidup pasien lansia pengguna gigi tiruan lepasan di Instalasi Prostodonsia RSGM Unpad.

\section{METODE PENELITIAN}

Penelitian ini merupakan penelitian deskriptif. Sampel adalah pasien lansia pengguna gigi tiruan lepasan di Instalasi Prostodonsia RSGM Unpad yang memenuhi kriteria inklusi. Teknik sampling yang digunakan adalah consecutive sampling yaitu pemilihan sampel dengan menetapkan subjek yang memenuhi kriteria penelitian dimasukkan dalam penelitian dalam kurun waktu tertentu. Penelitian dilakukan selama 1 bulan.

Kriteria inklusi minimal 60 tahun yang menggunakan gigi tiruan lepasan dan bersedia menjadi responden (kooperatif). Kriteria eksklusi adalah pasien yang memiliki kelainan pada gigi dan mulut yang menimbulkan rasa tidak nyaman, memiliki keterbatasan fisik maupun mental, pasien yang memiliki kebutuhan khusus dan tidak bersedia menjadi responden.

Alat ukur yang digunakan dalam penelitian ini adalah kuesioner GOHAl, merupakan salah satu instrumen untuk mengukur kualitas hidup yang berhubungan dengan kesehatan rongga mulut. Kuesioner GOHAI direkomendasikan untuk survey klinis dan epidemiologi yang menilai kesehatan rongga mulut pada lansia. Selain itu, kuesioner ini banyak digunakan di berbagai negara dan telah divalidasi. Jumlah pertanyaan kuesioner GOHAI cenderung lebih sedikit dibandingan kuesioner mengenai kualitas hidup lainnya.

Prosedur penelitian dimulai dari persiapan penelitian seperti pembuatan surat izin penelitian dan surat pembebasan etik (No: 442/UN6.C1.3.2/ 
KEPK/PN/2015), selanjutnya pelaksanaan penelitian dengan memilih pasien yang sesuai kriteria, pemberian kuesioner GOHAI kepada subjek penelitian untuk diisi dan mengumpulkan kuesioner.

Pengolahan data diperoleh dari hasil pengisian kuesioner GOHAI menggunakan tiga skala nilai, yaitu nilai 1 untuk jawaban yang selalu, nilai 2 untuk jawaban yang terkadang dan nilai 3 untuk jawaban yang tidak pernah. Jumlah nilai dikategorikan menjadi kategori baik, cukup, dan kurang menurut kriteria yang didapatkan dengan rumus:

$$
\begin{aligned}
\text { Skor kualitas hidup } & =\frac{\text { Skor tertinggi }- \text { skor terendah }}{\text { Interval }} \\
& =\frac{3-1}{3} \\
& =0,67
\end{aligned}
$$

Kriteria penilaian adalah apabila skor 0,0-1,67 berarti kualitas hidup kurang; skor 1,672,3 berarti kualitas hidup cukup; skor 2,4-3 berarti kualitas hidup baik. Data yang didapatkan akan diolah dengan cara sederhana dan disajikan dalam bentuk tabel dan perhitungan berupa persentase.

\section{HASIL PENELITIAN}

Berdasarkan hasil penelitian yang telah dilakukan kepada 31 orang pasien pengguna gigi tiruan lepasan di Instalasi Prostodonsia RSGM Unpad, diperoleh data mengenai karakteristik umum responden penelitian yang akan disajikan dalam Tabel $1-4$.

Tabel 1. Distribusi responden penelitian berdasarkan jenis kelamin

\begin{tabular}{lcc}
\hline Jenis kelamin & Frekuensi (orang) & Presentase (\%) \\
\hline Perempuan & 17 & 54,83 \\
Laki-laki & 14 & 45,17 \\
\hline Total & 31 & 100 \\
\hline
\end{tabular}

Tabel 2. Distribusi responden penelitian berdasarkan usia

\begin{tabular}{ccc}
\hline Umur & Frekuensi (orang) & Presentase (\%) \\
\hline $60-64$ & 26 & 83,87 \\
$65-69$ & 4 & 12,9 \\
$70-74$ & 0 & 0 \\
$75-79$ & 1 & 3,22 \\
\hline Total & 31 & 100 \\
\hline
\end{tabular}

Tabel 3. Distribusi responden penelitian berdasarkan jenis gigi tiruan

\begin{tabular}{lcc}
\hline Jenis gigi tiruan & $\begin{array}{c}\text { Frekuensi } \\
\text { (orang) }\end{array}$ & $\begin{array}{c}\text { Presentase } \\
\text { (\%) }\end{array}$ \\
\hline Gigi tiruan lepasan sebagian & 7 & 22,5 \\
Gigi tiruan lepasan penuh & 24 & 77,5 \\
\hline Total & 31 & 100 \\
\hline
\end{tabular}

Tabel 4. Distribusi responden penelitian berdasarkan lama penggunaan gigi tiruan

\begin{tabular}{lcc}
\hline $\begin{array}{l}\text { Lama penggunaan } \\
\text { gigi tiruan }\end{array}$ & Frekuensi (orang) & Presentase (\%) \\
\hline$<1$ bulan & 7 & 22,58 \\
$1-6$ bulan & 21 & 67,74 \\
$>6$ bulan & 3 & 9,67 \\
\hline Total & 31 & 100 \\
\hline
\end{tabular}

Kuesioner yang telah dibagikan kepada responden berisi 12 buah pertanyaan yang terbagi dalam tiga dimensi, yaitu fungsi fisik, nyeri dan ketidaknyamanan, serta aspek psikososial dengan 3 skala pengukuran. Hasil dari pengisian kuesioner oleh 31 responden berdasarkan kriteria Indeks GOHAl dapat dilihat pada Tabel 5 dan Tabel 6.

\section{PEMBAHASAN}

Dari hasil penelitian menunjukkan bahwa kualitas hidup pasien lansia pengguna gigi tiruan lepasan di RSGM Unpad berada dalam kategori baik yang dilihat dari tiga aspek yaitu aspek nyeri dan ketidaknyamanan serta aspek psikososial dalam penelitian ini dalam kategori baik, sedangkan aspek fungsi fisik dalam kategori cukup baik. Hasil ini menggambarkan bahwa gigi tiruan yang responden gunakan dapat meningkatkan kualitas hidupnya. Kualitas hidup sendiri merupakan istilah yang digunakan secara luas dalam berbagai konteks terkait dengan adanya dampak penyakit dan kesehatan pada pengalaman seseorang. Dalam penelitian Kusdhany dkk tahun 2011 dikatakan bahwa sesuai kebijakan World Health Organization (WHO), kesehatan gigi dan mulut merupakan bagian integral dan penting bagi kesehatan umum, yang merupakan faktor penentu kualitas hidup. ${ }^{3,14}$ 
Tabel 5. Indeks GOHAI pasien lansia pengguna gigi tiruan lepasan di instalasi prostodonsia RSGM Unpad

\begin{tabular}{|c|c|c|c|c|c|c|c|}
\hline \multirow[t]{2}{*}{ No. } & \multirow[t]{2}{*}{ Pertanyaan } & \multicolumn{2}{|c|}{ Selalu } & \multicolumn{2}{|c|}{ Terkadang } & \multicolumn{2}{|c|}{ Tidak Pernah } \\
\hline & & $\mathrm{n}$ & $\%$ & $\mathrm{n}$ & $\%$ & $\mathrm{n}$ & $\%$ \\
\hline 1 & $\begin{array}{l}\text { Membatasi jumlah atau jenis makanan yang anda } \\
\text { konsumsi karena kondisi gigi tiruan }\end{array}$ & 0 & $0 \%$ & 10 & $32 \%$ & 21 & $68 \%$ \\
\hline 2 & $\begin{array}{l}\text { Mengalami masalah saat mengunyah atau menggigit } \\
\text { berbagai jenis makanan, seperti daging utuh atau } \\
\text { buah apel }\end{array}$ & 0 & $0 \%$ & 21 & $68 \%$ & 10 & $32 \%$ \\
\hline 3 & Merasa nyaman saat menelan & 31 & $100 \%$ & 0 & $0 \%$ & 0 & $0 \%$ \\
\hline 4 & $\begin{array}{l}\text { Mengalami kesulitan berbicara sesuai dengan yang } \\
\text { diinginkan }\end{array}$ & 0 & $0 \%$ & 4 & $13 \%$ & 27 & $87 \%$ \\
\hline 5 & Makan tanpa merasakan gangguan & 0 & $0 \%$ & 23 & $74 \%$ & 8 & $26 \%$ \\
\hline 6 & $\begin{array}{l}\text { Membatasi diri anda dalam bersosialisasi dengan } \\
\text { orang lain karena kondisi gigi tiruan }\end{array}$ & 0 & $0 \%$ & 0 & $0 \%$ & 31 & $100 \%$ \\
\hline 7 & $\begin{array}{l}\text { Merasa puas atau senang dengan penampilan gigi } \\
\text { geligi atau gigi tiruan }\end{array}$ & 31 & $100 \%$ & 0 & $0 \%$ & 0 & $0 \%$ \\
\hline 8 & $\begin{array}{l}\text { Menggunakan obat-obatan untuk mengurangi rasa } \\
\text { sakit atau tidak nyaman pada rongga mulut }\end{array}$ & 0 & $0 \%$ & 0 & $0 \%$ & 31 & $100 \%$ \\
\hline 9 & $\begin{array}{l}\text { Merasa cemas atau khawatir dengan masalah gigi } \\
\text { geligi atau gigi tiruan }\end{array}$ & 0 & $0 \%$ & 4 & $12 \%$ & 27 & $88 \%$ \\
\hline 10 & $\begin{array}{l}\text { Merasa tidak percaya diri karena masalah yang dit- } \\
\text { imbulkan karena keadaan gigi geligi atau gigi tiruan }\end{array}$ & 0 & $0 \%$ & 0 & $0 \%$ & 31 & $100 \%$ \\
\hline 11 & $\begin{array}{l}\text { Merasa tidak nyaman saat makan di depan orang } \\
\text { lain karena keadaan gigi geligi atau gigi tiruan }\end{array}$ & 0 & $0 \%$ & 2 & $7 \%$ & 29 & $93 \%$ \\
\hline 12 & $\begin{array}{l}\text { Gigi atau gusi anda sensitif terhadap makanan atau } \\
\text { minuman hangat, dingin atau manis }\end{array}$ & 0 & $0 \%$ & 7 & $23 \%$ & 24 & $77 \%$ \\
\hline
\end{tabular}

Tabel 6. Indeks GOHAI pasien lansia pengguna gigi tiruan lepasan di instalasi prostodonsia RSGM Unpad

\begin{tabular}{|c|c|c|}
\hline Dimensi & Indeks GOHAI & Kriteria \\
\hline Fungsi fisik & 2,25 & Cukup \\
\hline Nyeri dan ketidaknyamanan & 2,55 & Baik \\
\hline Aspek psikososial & 2,50 & Baik \\
\hline Rata-rata & 2,4 & Baik \\
\hline
\end{tabular}

Berdasarkan jenis kelamin lebih banyak pasien perempuan pengguna gigi tiruan lepasan dibandingkan laki-laki. Hal tersebut dapat disebabkan karena perempuan lebih peduli terhadap kesehatan gigi dan mulutnya serta penampilannya daripada laki-laki dan jumlah penduduk lansia perempuan lebih banyak dibandingkan laki-laki. ${ }^{3}$ Pada penelitian Aghahossein dan Akhavan tahun 2003 menyebutkan perempuan mengalami fase menopause yang dapat mempengaruhi kondisi gigi dan mulutnya seperti menurunnya sekresi saliva. Menurunnya sekresi saliva dapat memicu penyakit periodontal dan karies sehingga dapat menyebabkan lepasnya gigi geligi. ${ }^{15}$

Pada penelitian ini ditemukan bahwa pasien lansia pengguna gigi tiruan lepasan yang datang ke RSGM Unpad memiliki rentang usia 60-79 tahun. Dalam penelitian Stayte tahun 2003 menyebutkan kesehatan gigi dan mulut pada pasien dengan usia tua di atas 65 tahun sering diabaikan dan dalam penelitian Hung tahun 2011 sebanyak $80 \%$ penduduk berusia di atas 65 tahun biasanya menderita satu atau lebih penyakit kronis sehingga terkadang mereka tidak mampu datang untuk berobat dan membutuhkan perlakuan khusus. ${ }^{7,16,17}$

Berdasarkan jenis penggunaan gigi tiruan ditemukan lebih banyak pengguna gigi tiruan lengkap dibandingkan gigi tiruan sebagian. Dalam penelitian Peltzer tahun 2014 dikatakan semakin bertambahnya usia maka lebih cenderung kehilangan seluruh giginya karena struktur, bentuk dan warna dari gigi akan berubah. ${ }^{18}$

Berdasarkan lama penggunaan gigi tiruan dapat dilihat bahwa rentang waktu terbanyak adalah 1-6 bulan. Hal ini dapat dipengaruhi oleh jadwal perjanjian pasien dan operator untuk datang kembali ke RSGM Unpad. Seluruh responden merasa nyaman ketika menelan dan 
87\% responden tidak mengalami kesulitan ketika berbicara. Hal ini sesuai pada penelitian Shigli dkk tahun 2007 yang mengatakan bahwa faktor estetik dan fonetik menjadi salah satu faktor pertimbangan penggunaan gigi tiruan. ${ }^{19}$ Hasil penelitian ini juga menunjukan tidak ada responden yang pernah menggunakan obat-obatan karena masalah gigi tiruan mereka. Hal ini menunjukan bahwa gigi tiruan mereka tidak banyak menimbulkan masalah yang cukup serius pada keadaan rongga mulutnya.

Pada hasil penelitian ini dapat dilihat bahwa sebagian responden memiliki masalah ketika menggunakan gigi tiruan saat digunakan untuk makan. Dalam penelitian Rachmani tahun 2003 menyebutkan kurangnya retensi dan stabilisasi pada gigi tiruan dapat menyebabkan terganggunya fungsi pengunyahan terutama pada gigi geligi bawah. ${ }^{20}$

Sebanyak $22 \%$ responden terkadang merasakan sensitif terhadap makanan atau minuman hangat, dingin atau manis. Hal ini dapat disebabkan karena adanya karies dan hipersensitif dentin. Karies dapat menimbulkan gejala ngilu atau nyeri terhadap makanan atau minuman hangat, dingin atau manis. Dalam penelitian Kielbassa tahun 2002 dijelaskan bahwa hipersensitivitas dentin didefinisikan sebagai rasa sakit yang berlangsung singkat dan tajam akibat adanya rangsangan terhadap dentin yang terbuka (terpapar lingkungan oral). ${ }^{21}$ Walaupun rasa sakit yang timbul hanya berlangsung singkat, namun hal ini dapat mengakibatkan proses makan menjadi sulit. ${ }^{22}$ Rasa sakit tersebut akan mempengaruhi kenyamanan dan kesehatan rongga mulut dan bila tidak diatasi akan menimbulkan defisiensi nutrisi pada penderitanya. ${ }^{23}$

Seluruh responden tidak pernah membatasi diri anda dalam bersosialisasi dengan orang lain karena kondisi gigi tiruannya dan merasa puas atau senang dengan penampilan gigi geligi atau gigi tiruan mereka. Hal ini sesuai dengan penelitian McMIllan dan Wong tahun 2004 yang menyimpulkan kehilangan gigi dapat mempengaruhi keadaan fisik dan psikologis seseorang, seperti berkurangnya tingkat kepercayaan diri dan keterbatasan aktivitas sosial. $^{24}$

\section{KESIMPULAN}

Kesimpulan hasil penelitian menunjukkan kualitas hidup lansia pengguna gigi tiruan lepasan di Instalasi Prostodonsia RSGM Unpad berada pada kategori yang baik, baik dari aspek nyeri dan ketidaknyamanan maupun aspek psikososial dan cukup dari aspek fungsi fisik. Berdasarkan penelitian ini penulis menyarankan dalam pembuatan gigi tiruan, dokter gigi harus mempertimbangkan segala aspek yang ada agar gigi tiruan dapat meningkatkan kualitas hidup penggunanya.

\section{DAFTAR PUSTAKA}

1. Departemen Sosial Republik Indonesia. Undang-Undang Republik Indonesia Nomor 13 Tahun 1998 Tentang Kesejahteraan Lanjut Usia. 2006. 2-3.

2. Othman WW, Muttalib KA, Bakri R, Doss JG, Jaafar N, Sailer NC, Chen S. Validation of the Geriatric Oral Health Assessment Index (GOHAI) in the Malay Language. $\mathrm{J}$ of Public Health Dentistry. 2006; 66(3): 199 - 204.

3. Badan Pusat Statistik. Sensus Penduduk 2010. 2010. Tersedia online pada http://sp2010.bps. go.id/index. php/site/tabel?tid=336\& $\mathrm{wid}=0$ (diakses 1 Mei 2014)

4. Bappenas. Proyeksi Penduduk Indonesia (Indonesia Population Projection) 2005-2025. Jakarta: Bappenas. 2008. 44 - 45.

5. Kementerian Sosial Republik Indonesia. Penduduk lanjut usia di Indonesia dan masalah kesejahteraannya. 2007. Tersedia online pada http://www.kemsos.go.id/modules.php?nam e=News\&file=article\&sid=522 (diakses 4 Mei 2014).

6. Nugroho W. Komunikasi dalam keperawatan gerontik. Jakarta: Medika Salemba. 2009. 3 - 5.

7. Stayte P, Patel D, Turner D, Ind R, Woodcook J. Oral healthcare for older people. British Dental Association. 2003. Tersedia online pada https://www.bda.org/dentists/ policy-campaigns/research/patient- care/ Documents/oral_healthcare_for_older_ people_report.pdf. (diakses 10 Juli 2015) 
8. Martono H, Pranaka K. Buku ajar geriatri (ilmu kesehatan lansia). Jakarta: Balai Penerbit FK UI. 2004. 7 - 19, 72 - 79, 694 - 704, $711-713,804-810$.

9. Ratmini NK, Arifin. Hubungan kesehatan mulut dengan kualitas hidup lansia. J IImu Gizi: 2(2). 2011; 139 - 147.

10. Binu G. Textbook of Complete Denture Prosthodontics. New Delhi: CBS Publishers \& Distributors. 2006. 1 - 4.

11. World Health Organization. WHOOQL: Measuring quality of life. 1997. Tersedia online pada http://www.who.int/mental_health/ media/68.pdf (diakses 4 Juni 2014)

12. Sadewo J. Gigi tiruan mampu meningkatkan kualitas hidup lansia. 2014. Tersedia online pada http://www.republika.co.id/berita/gayahidup/info-sehat/14/06/12/n725fu-gigi-tiruanmampu-meningkatkan-kualitas-hidup-lansia, (diakses 2 Januari 2015).

13. Bittar TO. A cross-sectional study of health related quality of life of piracibiba's elderly population. Rev. odonto ciênc. 2010; 25(2):126-131. Tersedia online pada http:// revistaseletronicas.pucrs.br/ojs/index.php/ fo/article/ download/4967/5330 (diakses 4 Januari 2015).

14. Kusdhany L, Sundjaja $\mathrm{Y}$, Fardaniah $\mathrm{S}$, Ismail R. Oral health related quality of life in Indonesian middle-aged and elderly women. Med J Indones. 2011; 20(1): 63 - 64.

15. Aghahosseini $F, K M H$ Akhavan. Evaluation of stimulated salivary flow rate in menopausal and post-menopausal women. Journal of Dental Medicine Tehran University of Medical Sciences. 2003; 16(2): 39-45. Tersedia online pada http://jdm.tums.ac.ir/browse.php?a id=416\&sid=1\&slc_lang=en (diakses 1 Mei 2015)

16. Hung WW, Ross JS Boockvar KS, Siu AL. Recent trends in chronic disease, impairment and disability among older adults in the United States. BMC Geriatrics. 2011. Tersedia online pada http://www.ncbi.nlm.nih.gov/ pmc/articles/ PMC3170191/?tool=pubmed (diakses 1 Juli 2015)

17. Taylor D. Physical activity is medicine for older adults. Postgrad Med J. 2014; 90: 26 - 32.

18. Peltzer K, Hewlett S, Yawson AE, Moynihan $P$, Preet R, Wu F, et al. Prevalence of loss of all teeth (edentulism) and associated factors in older adults in China, Ghana, India, Mexico, Russia and South Africa. Int J Environ Res Public Health. 2014; 11(11): 11308-11324.

19. Shigli K, Hebbal M, Angadi GS. Attitudes towards replacement of teeth among patients at the Institute of Dental Sciences, Belgaum, India. J Dent Educ. 2007; 71(11): 1467 - 1475.

20. Rachmani R. Desain basis geligi tiruan lengkap rahang bawah pada resorbsi tulang alveolar yang berlebihan. Majalah IImiah Kedokteran Gigi. 2003; 18(51): 23 - 30.

21. Kielbassa AM. Dentine hypersensitivity: Simple steps for everyday diagnosis and management. International Dental Journal. 2002; 52(2): 394 - 396.

22. Rizqy Al, Aminatun, Widiyanti P. Studi infiltrasi tubulus dentin berbasis hidroksiapatit yang berpotensi untuk terapi dentin hipersensitif. Departemen Fisika Universitas Airlangga. 2012. $1-4$.

23. Camila. Efficacy of Gluma Desensitizer $®$ on dentin hypersensitivity in periodontally treated patients. Braz Oral Res. 2006; 20(3): 252.

24. McMillan AS, Wong MCM. Emotional effect of tooth loss in community-dwelling elderly peoplein Hong Kong. Int J Prosthodont. 2004; 17(2): 172-6. Tersedia online pada http://www. ncbi.nlm.nih.gov/ pubmed/15119867 (diakses 4 Januari 2015). 